\title{
Sundanese flute: from Art and Physics perspective
}

\author{
Ika Mustika Sari \\ Dept. of Physics Education \\ Universitas Pendidikan Indonesia \\ Bandung, Indonesia \\ ikams@upi.edu
}

\section{Engkur Kurdita}

Study program of Music Art

Universitas Pendidikan Indonesia

Bandung, Indonesia

engkurdita@gmail.com

\author{
Khairil Anwar \\ Dept. of Physics Education \\ Universitas Muhammadiyah Mataram \\ Mataram, Indonesia \\ hairil_physics@yahoo.com
}

\author{
Nuryani Rustaman \\ Study Program of Science Education \\ Universitas Pendidikan Indonesia \\ Bandung, Indonesia \\ nuryani_rustaman@yahoo.com
}

\begin{abstract}
Suling sunda or Sundanese flute is a traditional wind instrument which comes from Sundanese tribe located in West Java Indonesia. Nowadays, the enthusiasm of young generation to learn and play the sundanese flute decreases from year to year. Whereas, sundanese flute is one of the unique musical instrument and it can produce touched tones. Conservation of the Sundanese Flute will increase the pride to be Sundanese and it increases the national character. Besides, Sundanese Flute can be a learning media in physics learning when discuss about sound, resonance, standing wave and open pipe. This study was focused to the organology, frequency and the wave form of each note of Sundanese flute and was directed to describe the organology, to measure the frequency and to display the wave form of each note of the Sundanese flute. The data was collected through semistructured interviews to the lecturer in Music Department whose focuses is traditional instruments; conducting experiment to measure the frequency and analyzing a music software to depict of wave form resulted from each note.
\end{abstract}

Keywords—sundanese flute, organology, frequency, wave form

\section{INTRODUCTION}

Nowadays, the young generations' interest to traditional music instrument is decreasing. They were more enthusiasts to learn and play modern instrument. On the other hand, traditional music instrument is unique and has a high esthetic value. Traditional music is a heritage and it should be conserved from the extinction. This phenomenon is relevant with the fact that happened in one of music study program. Most of students prefer modern instruments than traditional instruments. This led us to apprehensive about the extinctive of the traditional music.

Sundanese tribe which is located in West Java has a unique art, tradition and culture. They are well known as kind and frendly people. One of sundanese art is Karawitan. It involves a set of music instruments called gamelan. Gamelan consists of wind instrument (flute (suling)), stringed instruments (kecapi, rebab), metallophone instruments (saron, bonang, gong). Sundanese song accompanied by the gamelan is touching the heart and it can give a relaxing nuance. There are Sundanese songs that only accompanied by the suling(flute) and kecapi, is called Cianjuran.

Sundanese Flute plays an important role in giving a touched nuance while accompany sundanese song (kawih). Sundanese flute [Suling in West Java] has many variance, both kind and shape, tone that produced, laras(tuning/ scales)in Karawitan [1]. Sundanese flute is a wind instrument and it works based on resonance in open pipe [2]. So, based on the physics principles, Sundanese flute can be used as learning media when physics teacher wants to explain the concept of sound, resonance and standing wave in open pipe. So, we need deep explore about the Sundanese flute in two perspectives: art and physics. This study is a descriptive research about Sundanese flute from art perspective: explain about the organology, and from physics perspective: explain the trend of frequency and wave form of each tone.

Suling sunda / Sundanese Flute is a wind instrument made of specific bamboo that called tamiang [3]. Flute in Sumatera Island is known as term "saluang", while in Tegal City is called as "ilo-ilo". On the other hand, Yudibrata defined Suling is a horizontal wind instrument, made of small and tiny bamboo, that called tamiang, it has six holes for accompany sundanese song or kecapi suling, and it has four holes for salendro and degung tunings [1].

Suling sunda/bamboo sundanese flute is one of wind instrument, behave as open cylindrical pipe. When the air is blown to upper edge of flute (Elak-elakan), the air in column vibrates and in the end of Suling, it forms of antinode and the resonance is occurs. In open pipe, it has an antinode (and pressure node) in the end of pipe [4]. The frequency of resonance for pipe which both of ends is open, is equal to frequency for closed end pipe. But, it has an end correction in both ends. The wavelength of fundamental note is twice of pipe's effective length. Flute and recorder behave as open pipe with all the harmonic arise. It's like vibrate strings, the general motion of air molecules in open pipe is mixed of harmonics. 


\section{RESEARCH METHODS}

Research about Sundanese Flute was conducted to depict about the Sundanese flute from two perspectives: art and physics. This study is an ethno-science research. To explore Sundanese flute from the art perspective we conducted series of semi structured interviews to lecturer of music art whose focuses in traditional instruments. Moreover, we also did literature study about the organology, history and the trend of Sundanese flute. Organology is a study about the music instruments. Organology learns the structure of music instruments based on the source of sound, the way to produce sound and scales system. Organology can be studied from two approaches: Textual Study and Contextual Study. Textual Study is an approach that treats the study as text. The study object is an instrument itself and others instrument that have a same characteristic. From this study, we explore the material of Sundanese flute, kinds of it, the tones that produced by the Sundanese flute.

From the physics perspective, we used an experimental design. We measured the frequency and form of wave from each of the tones that produced by Sundanese Flute. An expert blows Sundanese Flute, then the sensitive microphone receive the sound and it was connected to the software that record and measure the frequency and wave form. The software that we used to measure frequency and displayed the wave form, is MacScope II. MacScope II is an audio software oscilloscope that works on Mac and Windows, using the computer's 16 bit audio input. MacScope is one of the sophisticated free software that helps us to describe the sound, both to measure the frequency and to analyze the sound.

\section{RESULT AND DISCUSSION}

\section{A. Organology}

Suling Sunda is made of specific bamboo, it is called tamiang (Schizostachyum blumei). Tamiang is different from common bamboo. It is small and tiny. The diameter is about $1-$ $2 \mathrm{~cm}$ with the thickness is about $1-1,5 \mathrm{~mm}$. The tamiang that is used to make Suling Sunda should be dried or ripe tamiang. Suling Sunda is different from another common flute in Indonesia. The unique characteristic of Suling Sunda is a cord that is made of rattan and it is located in upper part of Suling Sunda. The cord is known as SULIWER/ SUMBER/ SUWER. SULIWER is functioned for manage the air that is blown to Suling. Figure 1 shows the different of Suling from Sunda, Bali, etc. Fig. 1 shows that SULIWER/ rattan cord is the part that differ Suling Sunda from others Suling. Parts of Suling sunda are shown in the Fig. 2.

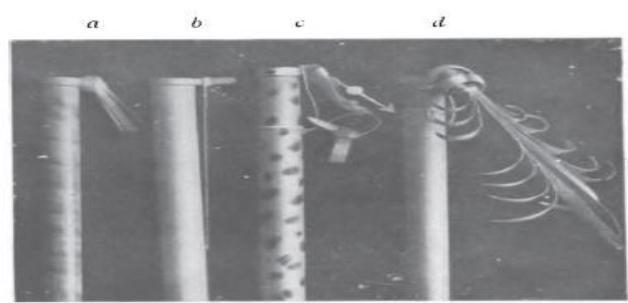

Fig. 1. Suling from: a. Sunda; b. Central Java; c. Madura; d. Bali (source: Kunst, J., and Heins, E.L. 1987 pp 433)

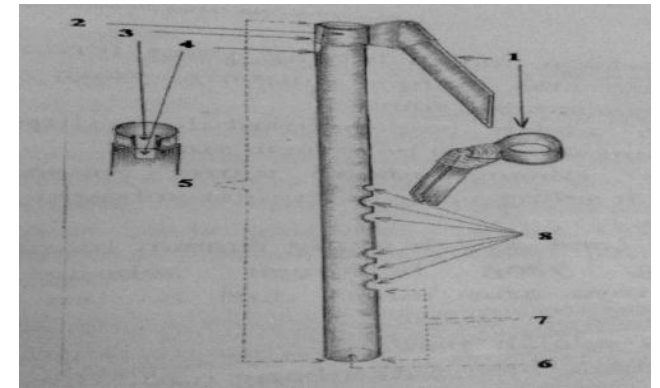

Fig. 2. Parts of Suling Sunda

\section{Explanation:}

1. Talisumber/suliwer/suwer is a cord that is made of rattan. It is attached togado. Suliwer is functioned for supporting air stream from mouth to Suling.

2. Gadois a part of Suling, is a place that Suliwer is attached. It is located in upper part of Suling.

3. Elak-elakan is a hole, it has functioned as a source of sound.

4. Letahis a part of Suling that is functioned to reflect the blow. It is a source of sound.

5. Laras/Watang is a place that sound resonance. It is called as a resonator.

6. Liang laras is a lower part of the Suling. It is functioned as a hole that air stream exit from resonator.

7. Rambu is a long part in the lowest part of Suling. It is located under the finger hole. It is functioned as an end of the sound resonance area.

8. Liang sora/liangsurupan is a finger hole. There are six finger holes in Suling. It is functioned as an exit of tones.

The length of Sundanese Flutewhich has six finger holes vary from $50 \mathrm{~cm}$ to $64 \mathrm{~cm}$. Sundanese Flute is divided in two groups: SulingKawih and SulingTembang. Suling Kawih has length $50 \mathrm{~cm}$ to $57 \mathrm{~cm}$. The $50 \mathrm{~cm}-54 \mathrm{~cm}$ long Sulingkawih is commonly used by children. While the $55 \mathrm{~cm}-57 \mathrm{~cm}$ is commonly used by adults and it is functioned as a part of Gamelan Degung. Suling tembang has longer length from Suling Kawih that vary from $58 \mathrm{~cm}$ to $64 \mathrm{~cm}$. Sulingtembang that length $58-61 \mathrm{~cm}$ is commonly used as song accompaniment. While Suling that length $62 \mathrm{~cm}, 63 \mathrm{~cm}$ and 64 $\mathrm{cm}$ is usually used in instrumental because the longer the pipe, the lower the resulting tone. In West Java, Sulingtembang that is commonly used is Sulingtembang that $60-61 \mathrm{~cm}$ long, due to the pitch of the singers. The resulting tones on Sundanese Flute is pentatonic i.e. $\mathrm{Da}, \mathrm{Mi}, \mathrm{Na}, \mathrm{Ti}$, La. Fig. 3 described the resulting tones from the combination of closing the finger holes.

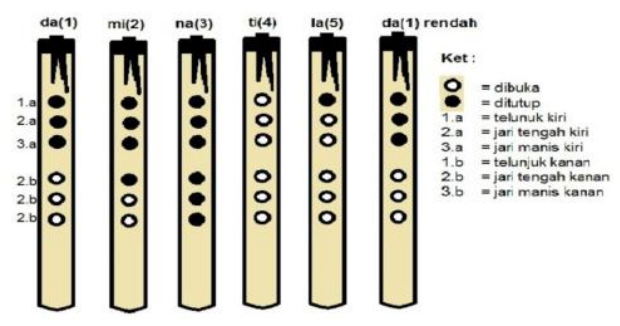

Fig. 3. the tone types of PelogDegung Tuning 
Sundanese Flute has six or four finger holes. The four finger holes Sundanese Flute is simplification from six finger holes suling. It have different tuning system. The-six-finger-holes Suling has three tuning systems: Pelog Degung tuning, Salendro tuning, and Madenda tuning. The resulting tones from Sundanese Flute, $\mathrm{Da}$, Mi, Na, Ti, La could be matched to diatonic tones (Table I-III)

TABLE I. PELOG DEGUNG TUNING SYSTEM

\begin{tabular}{|l|c|c|c|c|c|c|}
\hline Pentatonic & Da (1) & Mi (2) & Na (3) & Ti (4) & La (5) & Da (1.) \\
\hline Diatonic & Do (1') & Si (7) & Sol (5) & Fa (4) & Mi (3) & Do (1) \\
\hline Pentatonic & Da (1) & Mi (2) & Na (3) & Ti (4) & La (5) & Da (1.) \\
\hline Diatonic & Fa(4') & Mi (3') & Do (1') & Si (7) & La (6) & Re (2)) \\
\hline Pentatonic & $\mathrm{Da}(1)$ & Mi (2) & Na (3) & Ti (4) & La (5) & Da (1.) \\
\hline Diatonic & Re (2') & Do (1') & La (6) & Sol (5) & Fa (4) & Re (2) \\
\hline
\end{tabular}

\section{B. Sundanese Flute: Physics Perspective}

Bamboo sundanese flute is one of wind instrument, behave as open cylindrical pipe. When the air is blown to upper edge of flute (Elak-elakan), the air in column vibrates and in the end of Suling, it forms of antinode and the resonance is occurs. In open pipe, it has an antinode (and pressure node) in the end of pipe [4]. The frequency of resonance for pipe which both of ends is open, is equal to frequency for closed end pipe. But, it has an end correctionin both ends. The wavelength of fundamental note is twice of pipe's effective length. Flute and recorder behave as open pipe with all the harmonic arise. It's like vibrate strings, the general motion of air molecules in open pipe is mixed of harmonics.

TABLE IV.

FREQUENCY OF EACH NOTE IN PELOG TUNING ( SULING KAWIH, LENGTH 56 CM)

\begin{tabular}{|c|c|c|c|}
\hline \multirow{2}{*}{ No } & \multicolumn{2}{|c|}{ Notes } & \multirow{2}{*}{$\begin{array}{c}\text { Fundamental } \\
\text { Notes (Hz) }\end{array}$} \\
\cline { 2 - 3 } & Symbol & Name & 1688,4 \\
\hline 1 & 1. & Da. & 1567,8 \\
\hline 2 & 2. & Mi. & 1186,4 \\
\hline 3 & 3. & Na. & 1125,6 \\
\hline 4 & 4. & Ti. & 997,7 \\
\hline 5 & 5. & La. & 812,9 \\
\hline 6 & 1 & Da & 756,9 \\
\hline 7 & 2 & Mi & 593,2 \\
\hline 8 & 3 & Na & 522,6 \\
\hline 9 & 4 & Ti & 493,2 \\
\hline 10 & 5 & La & 391,9 \\
\hline 11 & 1 & Da' & 378,4 \\
\hline 12 & 2 & Mi' & 292,7 \\
\hline 13 & 3 & Na' & \\
\hline
\end{tabular}

In Suling, the notes are produced from the vibrating of air particles in the tube, which is called a resonator/ Laras/ Watang (number 5 in Fig. 2). The notes are resulting when Suling is blown and the finger holes are combination closed. At that time, resonance is occurs and it results notes. Every notes in each tuning has unique frequency. The frequency is shown in Table IV-VI.

TABLE V. FREQUENCY OF EACH NOTE IN MADENDA TUNING ( Suling KAWIH , LENGTH 56 CM)

\begin{tabular}{|c|c|c|c|}
\hline \multirow[t]{2}{*}{ No } & \multicolumn{2}{|c|}{ Notes } & \multirow{2}{*}{$\begin{array}{c}\text { Fundamental } \\
\text { Notes }(\mathrm{Hz})\end{array}$} \\
\hline & Symbol & Name & \\
\hline 1 & 3. & $\mathrm{Na}$. & 1567,8 \\
\hline 2 & 4. & Ti. & 1513,7 \\
\hline 3 & 5. & La. & 1330,2 \\
\hline 4 & 1 & $\mathrm{Da}$ & 1045,2 \\
\hline 5 & 2 & Mi & 975,5 \\
\hline 6 & 3 & $\mathrm{Na}$ & 770,1 \\
\hline 7 & 4 & $\mathrm{Ti}$ & 731,6 \\
\hline 8 & 5 & $\mathrm{La}$ & 675,4 \\
\hline 9 & 1, & Da' & 510,4 \\
\hline 10 & $2^{\prime}$ & Mi’ & 504,6 \\
\hline 11 & $3^{\prime}$ & $\mathrm{Na}$ & 391,9 \\
\hline 12 & $4^{\prime}$ & Ti' & 354,0 \\
\hline 13 & $5^{\prime}$ & La' & 330,1 \\
\hline
\end{tabular}

TABLE VI.

FREQUENCY OF EACH NOTE IN SALENDRO TUNING ( SULING KAWIH, LENGTH 56 CM)

\begin{tabular}{|c|c|c|c|}
\hline \multirow{2}{*}{ No } & \multicolumn{2}{|c|}{ Notes } & \multirow{2}{*}{ Fundamental } \\
Notes (Hz)
\end{tabular}

From Table IV, the highest frequency of fundamental notes is in the Pelog tuning, 1688,4 Hz for note $\mathrm{Da}$. The lowest frequency of fundamental notes is in the Salendro Tuning, 48,8 $\mathrm{Hz}$ for note $\mathrm{Na}$ '. For the same notes, i.e. $\mathrm{Na}$. in Pelog Tuning is 
lower than Na. in Salendro tuning and Na. in Madenda tuning. Generally, in the same note in each tuning system, The frequency of fundamental notes of Madenda tuning is always the highest than others two tuning systems.

On the other aspect, the wave forms of every note in each tuning system are described in Table VII for SulingKawih length $56 \mathrm{~cm}$. From Table VII, it was found that every note in every tuning has a unique wave form. The lower the notes, the more ripples in the wave form. Inversely, the higher the notes, the more smooth the wave form.

TABLE VII. The wave form of each notes for SulingKawih length $56 \mathrm{~cm}$

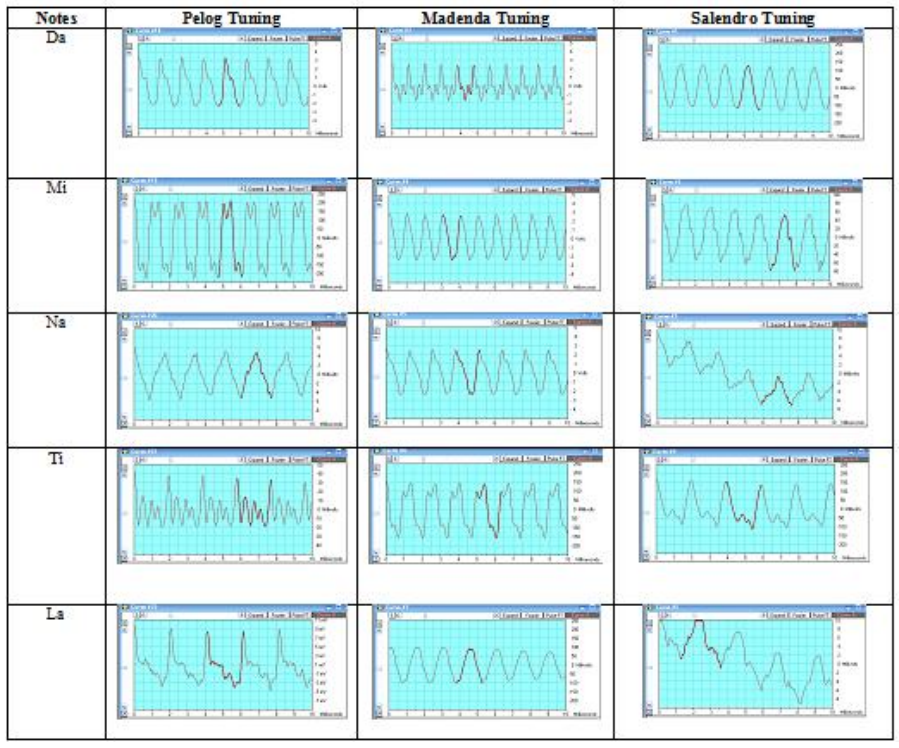

\section{CONCLUSION}

Sundanese flute is one of the sundanese heritage and it has unique character either from organology or the notes it's produced. One of unique character that is differed from others bamboo wind instruments is SULIWER/ SUMBER/ SUWER. The resulting notes are pentatonic notes: $\mathrm{Da}, \mathrm{Mi}, \mathrm{Na}, \mathrm{Ti}, \mathrm{La}$. There are three tuning system in Sundanese Flute i.e. Pelog Degung, Madenda, and Salendro. The resulting tones give a relaxed nuance.
Sundanese Flute is an open cylindrical column air. The blow air, vibrates in the column and it resonance in column of Flute. The combination of closing finger holes results the types of notes. The frequency of each note is different. The frequency and wave form of each note were measured by MacScope II, a software that can measure the frequency and the speed of sound and analyze the wave form. Sundanese Flute can be an alternative learning media in studying concept of sounds, resonance, sounds and wave propagation in open cylindrical column air.

Further study and analysis is needed to describe the relation of thickness and length of Flute to the resulting notes. Moreover, the collaborative work between the artist and physicist is still needed to be done, to create the new methods to calibrate the Sundanese Flute. So that, Sundanese Flute easy to be designed, and it will more famous in young Sundanese generation.

\section{Acknowledgment}

This study was supported by Laboratory of Physics Education FPMIPA UPI and Laboratory of Wind Instruments Music Education Department of FPBS UPI. We thank to the staff and the head of each Laboratory for supporting us in this research.

\section{References}

[1] E. Kurdita, "Bermain Suling Daerah Sunda," Bandung, INA: Bintang Warli Artika, 2011.

[2] J. Kunst, and E. L. Heins, "Music in Java, Its History, Its Theory, and Its Technique. Netherland: The Hague Martinus Nijhoff, 1973.

[3] A. Sopandi, "Kamus istilah karawitan sunda," Bandung, INA:1995.

[4] P. A. Tipler, "Fisika untuk Sains dan Teknik," Jakarta, INA: 1998

[5] D. R. Raichel, "The Science and Applications of Acoustics. Springer, 2006.

[6] R. A. Serway and C. Vuille, "College Physics tenth edition Volume 1," Cengage Learning, 2015.

[7] A. N. Weintraub, "Instruments of Power: Sundanese "Multi-Laras" Gamelan in New Order Indonesia," University of Illinois Press, 2001 